\title{
ANALISIS PENJUALAN BERSIH, BEBAN UMUM \& ADMINISTRASI TERHADAP LABA TAHUN BERJALAN
}

\author{
Denny Putri Hapsari \\ denny.putri@ rocketmail.com \\ Ade Saputra \\ Universitas Serang Raya
}

\begin{abstract}
ABSTRAK
Penelitian ini bertujuan untuk mengetahui pengaruh penjualan bersih, beban umum \& administrasi terhadap laba tahun berjalan pada perusahaan sektor industri dasar \& kimia yang terdaftar di bursa efek Indonesia. Dengan menggunakan teknik purposive sampling, diperoleh sampel sebanyak 18 perusahaan.Pada penelitian ini menggunakan metode analisis linier berganda dengan menggunakan uji asumsi klasik dan uji hipotesis. Dan data dikumpulkan dengan studi kepustakaan, mengambil dari bursa efek indonesia dan dianalisis dengan menggunakan aplikasi SPPS versi 21. Berdasarkan hasil penelitian dapat disimpulkan bahwa hasil analisis regresi secara parsial variabel penjualan bersih (X1) berpengaruh signifikan terhadap laba tahun berjalan, dimana nilai t hitung $>\mathrm{t}$ tabel $(5,306>1,998)$ dan beban umum \& administrasi (X2) tidak berpengaruh secara signifikan terhadap laba tahun berjalan $(0,773<$ 1,998). Untuk uji koefisien determinasi diperoleh adjusted $\mathrm{R}^{2} 0,724$, artinya $72,4 \%$ laba tahun berjalan dipengaruhi oleh kedua varibel tersebut. Sedangkan sisanya 27,6\% dipengaruhi oleh varibel lain yang tidak diteliti dalam penelitian ini.
\end{abstract}

Kata Kunci: Beban Umum \& Administrasi, Laba Tahun Berjalan, Penjualan Bersih.

\section{PENDAHULUAN}

Tujuan utama suatu perusahaan adalah mencapai laba bersih yang maksimal. Penilaian kinerja keuangan dapat digunakan untuk mengetahui seberapa besar keuntungan perusahaan dengan membandingkan hasil laba pada tahun tertentu dengan laba tahun-tahun berjalan sebelum dan sesudahnya. Dengan diketahuinya kesulitan keuangan sedini mungkin, maka pihak perusahaan dapat mengambil langkah-langkah bagaimana untuk memperbaiki kinerja perusahaan agar dapat meningkatkan laba di masa yang akan datang. Untuk menghasilkan laba atau pendapatan tentunya perusahaan harus rela mengeluarkan biaya yang berhubungan dengan kegiatan operasi perusahaan tersebut. Pendapatan dan beban tidak dapat dipisahkan, di mana pendapatan adalah hasil yang dapat diperoleh dari kegiatan operasi yang dilakukan perusahaan, sedangkan beban adalah biaya yang dikeluarkan atau digunakan untuk memperoleh pendapatan yang diharapkan oleh perusahaan. Perusahaan perlu memperhatikan pendapatan yang diterima dan pengeluaran yang dilakukan selama kegiatan operasi berlangsung agar perusahaan dapat menghasilkan laba yang diinginkan demi keberlangsungan usahanya. Jika pendapatan terlalu besar dari beban maka perusahaan akan memperoleh laba dan sebaliknya jika pendapatan lebih kecil dari biaya yang dikeluarkan maka perusahaan akan mengalami kerugian. Karena laporan keuangan digunakan oleh berbagai pihak, baik pihak intern maupun pihak ekstern untuk pengambilan keputusan dimasa yang akan datang, maka pendapatan dan beban perlu diperhatikan. (Meiza, 2014). Kondisi laba suatu perusahaan merupakan salah satu faktor penentu berhasil atau tidaknya suatu perusahaan dalam menjalankan usahanya. Laba terdiri dari berbagai jenis, seperti laba kotor, laba bersih, laba tahun berjalan, dan lain-lain. Laba tahun berjalan yang terdapat pada suatu perusahaan biasanya dipengaruhi oleh beberapa faktor seperti penjualan dan harga pokok penjualan. (Arief, 2012) Perolehan laba perusahaan salah satunya dipengaruhi oleh faktor penjualan, selain itu faktor lain yang mempengaruhi besarnya laba perusahaan adalah harga jual dari 
produk tersebut. Harga jual merupakan masalah tersendiri yang harus dapat perhatian dari pihak manajemen karena dengan harga jual yang wajar maka target penjualan akan tercapai dan perusahaan akan memperoleh laba sesuai dengan yang diharapkan. (R Rosidi, 2006). Berdasarkan analisa terhadap beberapa laporan keuangan perusahaan Industri Dasar \& Kimia yang tedaftar di Bursa Efek Indonesia, tentunya tiap perusahaan memiliki fluktuasi yang berbeda-beda terhadap jumlah laba yang didapat tiap tahunnya.

\section{TINJAUAN PUSTAKA Penjualan}

Penjualan menurut William G. Nickels (1998 : 10), adalah Proses dimana sang penjual memuaskan segala kebutuhan dan keinginan pembeli agar dicapai manfaat baik bagi sang penjual maupun sang pembeli yang berkelanjutan dan yang menguntungkan kedua belah pihak. Menurut Winardi (1999, Hal. 176), menyatakan bahwa penjualan adalah hasil yang dicapai sebagai imbalan jasa-jasa yang diselenggarakan yang dilakukannya perniagaan transaksi dunia usaha.Menurut Komaruddin (1997, Hal 76), menyatakan bahwa Penjualan adalah kegiatan untuk menukarkan barang dan jasa khususnya dengan uang.Dilihat dari sudut penjualan berarti kegiatan untuk mendapatkan pembeli.Menurut Moekijat dalam buku Kamus istilah ekonomi menyatakan bahwa "Selling (melakukan penjualan) adalah suatu kegiatan yang ditujukan untuk mencari pembeli, mempengaruhi dan memberikan petunjuk agar pembeli dapat menyesuaikan kebutuhannya dengan produk yang ditawarkan serta mengadakan perjanjian mengenai harga yang menguntungkan bagi kedua belah pihak". (2000;488). Dari beberapa pengertian penjualan, dapat ditarik kesimpulan bahwa penjualan adalah penyerahan barang dan jasa atau aktivitas lainnya dalam periode tertentu dengan membebankan suatu jumlah tertentu kepada langganan atau konsumen. Dalam penelitian ini, penjualan yang digunakan adalah penjualan bersih.Menurut Soemarso dalam bukunya Akuntansi Suatu Pengantar (1999:124), penjualan bersih (net sales) adalah penjualan (pada nilai faktur) dikurangi dengan pengembalian, pengurangan harga, biaya transport yang dibayar untuk langganan dan potongan penjualan yang diambil. Jadi dapat disimpulkan bahwa penjualan bersih adalah seluruh hasil penjualan baik tunai maupun kredit, dikurangi dengan potongan penjualan dan retur penjualan, selain itu perusahaan juga harus membayar cukai dan pajak, dan lainnya.

\section{Beban}

Menurut Raja Adri Satriawan Surya dalam buku Akuntansi Keuangan versi IFRS, (2012:20) mendefinisikan beban sebagai berikut: "Beban (expenses) adalah penurunan manfaat ekonomi selama satu periode akuntansi dalam bentuk arus keluar atau berkurangnya aset atau terjadinya liabilitas yang mengakibatkan penurunan ekuitas yang tidak menyangkut pembagian kepada penanam modal.Definisi beban mencakup baik beban yang timbul dalam pelaksanaan aktivitas perusahaan yang biasa maupun kerugian (loss)". Menurut Supriyono, (2011: 14), expense (beban) adalah "Biaya yang dikorbankan atau dikonsumsi dalam rangka memperoleh pendapatan (revenues) dalam suatu periode akuntansi tertentu". Dari beberapa pengertian beban-beban yang telah dikemukakan para ahli di atas, dapat ditarik kesimpulan bahwa beban adalah berhubungan dengan berkurangnya arus kas, akan tetapi tidak bersangkutan dengan penanaman modal perusahaan. Dalam penelitian ini, beban yang digunakan adalah beban umum dan administrasi.Beban umum \& administrasi dalam hal ini dimaksudkan sebagai biaya-biaya yang terjadi dalam hubungannya dengan kegiatan-kegiatan yang tidak diidentifikasikan dengan aktivitas produksi maupun pemasaran. Biaya umum \& administrasi adalah biaya yang terjadi dalam hubungannya dengan penyusunan kebijakan dan pengarahan perusahaan secara keseluruhan.Contoh dari beban umum \& administrasi adalah gaji direksi, biaya sumbangan-sumbangan, gaji eksekutif, biaya telepon dan biaya lain-lain. 


\section{Laba}

Menurut Zaki Baridwan (2000;31) : "Laba (Gains) adalah kenaikan modal (aktiva bersih) yang berasal dari transaksi yang jarang terjadi dari suatu badan usaha, dan dari transaksi atau kejadian lain yang mempengaruhi badan usaha selama satu periode kecuali yang timbul dari pendapatan (revenue) atau investasi oleh pemilik". Laba menurut Sofyan Syahfri Harahap $(2001 ; 115)$ : "Gain (laba) naiknya nilai equity dari transaksi yang sifatnya insidentil dan bukan kegiatan utama (entity) dari transaksi atau kejadian lainnya yang mempengaruhi entity selama satu periode tertentu kecuali yang berasal dari hasil atau investasidari pemilik". Dari beberapa pengertian laba dapat disimpulkan bahwa laba adalah selisih lebih antara pendapatan dan beban yang timbul dalam kegiatan utama atau sampingan di perusahaan selama satu periode.Sedangkan yang dimaksud dengan laba tahun berjalan adalah "Laba yang diperoleh dalam tahun buku berjalan setelah dikurangi taksiran utang pajak.Jumlah laba tahun buku berjalan yang diperhitungkan sebagai modal inti hanya sebesar 50\%.Jika bank atau usaha mengalami kerugian pada tahun berjalan, seluruh kerugian tersebut menjadi faktor pengurang dari modal inti”.

\section{Kerangka Pemikiran}

Salah satu informasi yang harus disajikan dalam laporan laba rugi adalah pendapatan sebagai penghasil yang timbul dari aktivitas normal perusahaan yang biasa disebut penjualan. Pada umumnya perusahaan melakukan kegiatan penjualan untuk memperoleh laba yang maksimal dan untuk mempertahankan kelangsungan hidup perusahaan. Tingkat penjualan suatu perusahaan akan mempengaruhi laba yang didapat. Bila penjualan meningkat, maka laba perusahaan akan bertambah. Apabila penjualan menurun, maka laba perusahaan pun akan mengalami penurunan. Begitu pula dengan perubahan peningkatan dan penurunan beban. Apabila beban perusahaan meningkat, maka laba yang didapat akan mengalami penurunan. Dan juga sebaliknya, apabila beban perusahaan mengalami penurunan, maka laba akan bertambah. Maka dari itu perubahan penjualan dan beban berpengaruh berlawanan terhadap laba suatu perusahaan.

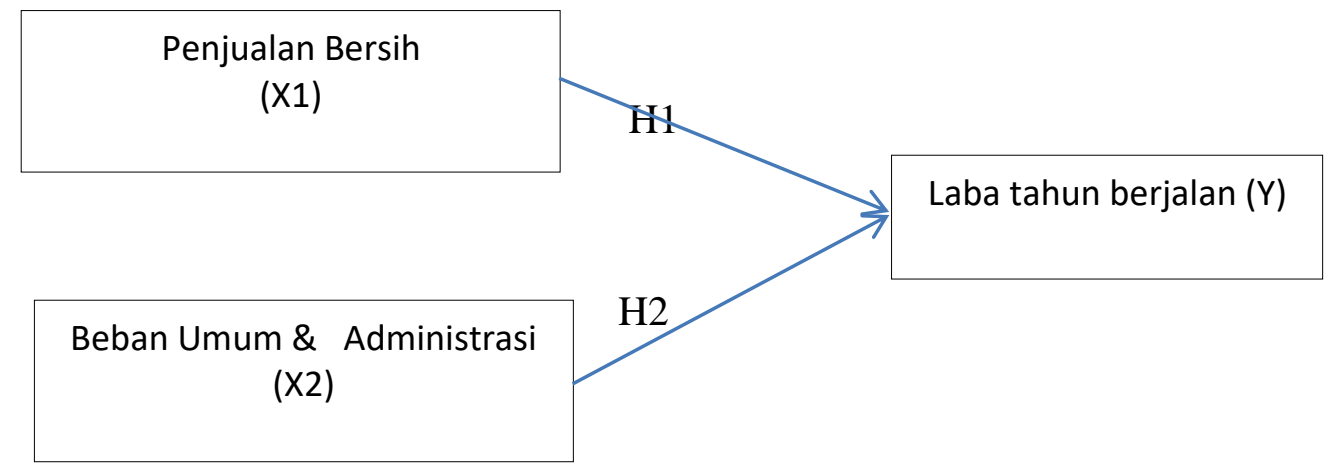

Berdasarkan kajian teori dan kerangka pemikiran yang telah dikemukakan di atas, maka hipotesis penelitian ini adalah sebagai berikut:

H1 : Penjualan Bersih berpengaruh signifikan terhadap laba tahun berjalan

$\mathrm{H} 2$ : Beban Umum \& Administrasi berpengaruh signifikan terhadap laba Tahun berjalan

\section{METODE PENELITIAN}

Dalam penelitian ini, penulis menggunakan desain penelitian kausalitas.Desain penelitian kausalitas adalah desain penelitian yang disusun untuk meneliti kemungkinan 
adanya hubungan sebab-akibat antara variabel.Dalam desain ini, umumnya hubungan sebab akibat (tersebut) sudah dapat diprediksi oleh peneliti, sehingga peneliti dapat menyatakan klasifikasi variabel penyebab, variabel antara dan variabel terikat. Populasi dalam penelitian ini adalah perusahaan sektor industri dasar dan kimia yang terdaftar di Bursa Efek Indonesia (BEI) dengan periode pengamatan 2011-2015 yang berjumlah 65 perusahaan.Teknik pengambilan sampel secara purposive sampling, sampel yang didasarkan pada pertimbangan pribadi peneliti sendiri, sesuai dengan kriteria sampel yang ditentukan. Adapun kriteria yang digunakan untuk mengambil sampel adalah: a. Perusahaan sektor industri dasar \& kimia yang masih terdaftar di BEI pada periode pengamatan 2011-2015. b. Telah menerbitkan laporan keuangan secara lengkap yang berakhir pada 31 Desember selama periode pengamatan. c. Memperoleh laba tahun berjalan (tidak mengalami kerugian selama periode pengamatan).

\section{Teknik Analisis}

Metode analisis yang digunakan dalam penelitian ini adalah analisis regresi linier berganda. Dalam penelitian ini menggunakan alat bantu SPPS (Statistical Product and Service Solution) versi 21. Dalam analisis ini terdiri dari uji statistik deskriptif, uji asumsi klasik (uji normalitas, autokorelasi, multikoloniearitas, dan heteroskedastisitas), analisis regresi linier berganda dan uji hipotesis (uji t, dan koefisien determinasi).

\section{HASIL PENELITIAN DAN PEMBAHASAN}

Descriptive Statistics

\begin{tabular}{lrrrrr}
\hline & N & \multicolumn{1}{c}{ Minimum } & \multicolumn{1}{c}{ Maximum } & \multicolumn{1}{c}{ Mean } & \multicolumn{1}{c}{ Std. Deviation } \\
\hline Penjualan Bersih & 90 & 174.599 & 26.987 .035 & $4.963 .229,17$ & $7.415 .753,019$ \\
Beban Umum \& & 90 & 5.921 & 2.087 .885 & $260.971,18$ & $487.298,092$ \\
$\begin{array}{l}\text { Administrasi } \\
\text { Laba Tahun }\end{array}$ & 90 & 1.854 & 5.567 .660 & $682.689,08$ & $1.477 .058,643$ \\
Berjalan & & & & & \\
\hline Valid N (listwise) & 90 & & & &
\end{tabular}

Berdasarkan tabel di atas, dapat diketahui bahwa jumlah data yang dimasukkan dalam pengujian ini berjumlah 90 data. Penjualan bersih yang memiliki nilai minimum sebesar 174.599, nilai maximum sebesar 26.987.035, nilai mean sebesar 4.963.229,17 dan nilai standar deviasinya sebesar 7.415.753,019. Beban Umum \& Administrasi yang memiliki nilai minimum sebesar 5.921, nilai maximum sebesar 2.087.885, nilai mean sebesar 260.971,18 dan nilai standar deviasinya sebesar 487.298,092. Laba tahun berjalan yang memiliki nilai minimum sebesar 1.854, nilai maximum sebesar 5.567.660, nilai mean sebesar 682.689,08 dan nilai standar deviasinya sebesar 1.477.058,643.

\section{Uji Asumsi Klasik}

Hasil Uji Kolmogorov-Smirnov One-Sample Kolmogorov-Smirnov Test

\begin{tabular}{|c|c|c|}
\hline & & $\begin{array}{l}\text { Unstandardized } \\
\text { Residual }\end{array}$ \\
\hline $\mathrm{N}$ & & 90 \\
\hline \multirow{3}{*}{ Normal Parameters ${ }^{\mathrm{a}, \mathrm{b}}$} & Mean &, 0000000 \\
\hline & Std. Deviation & 1,04432279 \\
\hline & Absolute &, 137 \\
\hline \multirow[t]{2}{*}{ Most Extreme Differences } & Positive & 074 \\
\hline & Negative &,- 137 \\
\hline Kolmogorov-Smirnov Z & & 1,300 \\
\hline Asymp. Sig. (2-tailed) & & ,068 \\
\hline
\end{tabular}


Berdasarkan tabel di atas, dapat diketahui bahwa jumlah sampel yang dimasukan dalam pengujian ini adalah 90 data. Nilai Kolmogorov-Smirnov Z sebesar 1,300 dan nilai signifikannya (Asymp. Sig. (2-tailed) sebesar 0,068>0,05 yang berarti data residual berdistribusi normal atau $\mathrm{H} 0$ diterima

\section{Uji Autokorelasi}

\begin{tabular}{lr}
\multicolumn{2}{c}{ Runs Test } \\
\hline Test Value $^{\mathrm{a}}$ & Unstandardized Residual \\
Cases $<$ Test Value &, 33491 \\
Cases $>=$ Test Value & 45 \\
Total Cases & 45 \\
Number of Runs & 90 \\
Z & 41 \\
Asymp. Sig. (2-tailed) & $-1,060$ \\
&, 289 \\
\hline
\end{tabular}

Dari tabel di atas hasil run test meunjukkan bahwa nilai Asymp. Sig. (2-tailed) > 0.05, maka H0 diterima dan HA ditolak. Hal ini berarti data residual terjadi secara acak (random). Dengan demikian, data yang dipergunakan tidak terdapat masalah autokorelasi.

\section{Uji Multikolinieritas}

\section{Hasil Uji Multikolinieritas}

Coefficients $^{\mathrm{a}}$

\begin{tabular}{|c|c|c|c|c|c|c|c|}
\hline \multirow{2}{*}{ Model } & \multicolumn{2}{|c|}{$\begin{array}{l}\text { Unstandardized } \\
\text { Coefficients }\end{array}$} & \multirow{2}{*}{$\begin{array}{l}\text { Standardize } \\
\mathrm{d} \\
\text { Coefficients } \\
\text { Beta }\end{array}$} & \multirow{2}{*}{$\mathrm{T}$} & \multirow{2}{*}{ Sig. } & \multicolumn{2}{|c|}{$\begin{array}{l}\text { Collinearity } \\
\text { Statistics }\end{array}$} \\
\hline & $\mathrm{B}$ & $\begin{array}{l}\text { Std. } \\
\text { Error }\end{array}$ & & & & Tolerance & VIF \\
\hline (Constant) & $-5,557$ & 1,262 & & $-4,402$ & ,000 & & \\
\hline Ln_Penjualan Bersih & 1,068 & ,201 & ,753 & 5,306 & ,000 &, 154 & 6,497 \\
\hline $\begin{array}{l}\text { Ln_Beban Umum \& } \\
\text { Administrasi }\end{array}$ & , 148 & ,191 &, 110 & ,773 & ,441 &, 154 & 6,497 \\
\hline
\end{tabular}

a. Dependent Variable: Ln_Laba Tahun Berjalan

Berdasarkan hasil uji multikolinieritas pada tabel di atas dapat dilihat bahwa Penjualan Bersih dan Beban Umum \& Administrasi menunjukkan nilai tolerance $>0,10$ dan nilai VIF < 10. Oleh karena itu dapat disimpulkan bahwa variabel independen yang digunakan dalam model regresi penelitian ini adalah terbebas dari multikolinieritas atau dapat dipercaya dan obyektif.

\section{Uji Heteroskedastisitas}




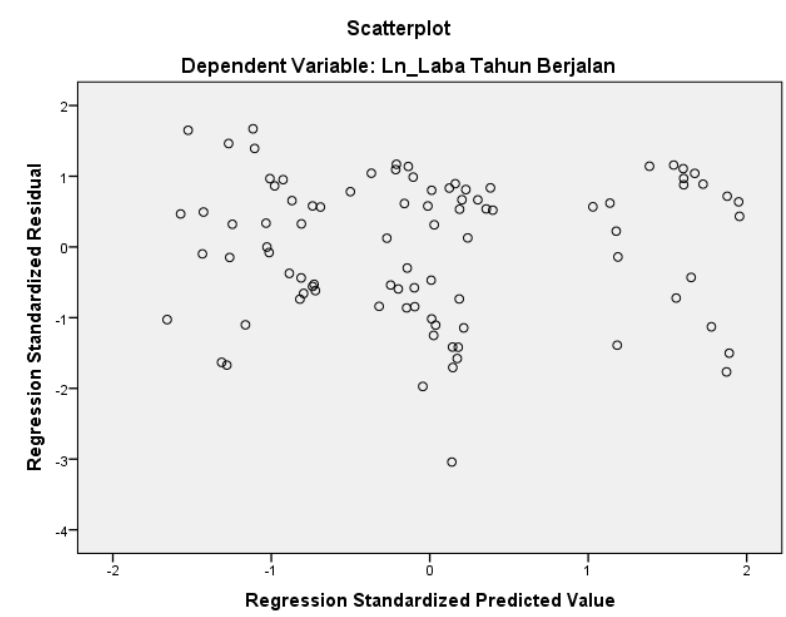

Berdasarkan hasil uji heteroskedastisitas pada gambar di atas, maka dapat disimpulkan bahwa dalam model regresi tersebut tidak terjadi heteroskedastisitas. Karena tidak ada pola yang jelas, serta titik-titik yang menyebar di bawah dan di atas angka nol pada sumbu Y.

\begin{tabular}{|c|c|c|c|c|c|c|}
\hline \multicolumn{7}{|c|}{$\begin{array}{c}\text { Hasil Uji Regresi Linier Berganda } \\
\text { Coefficients }\end{array}$} \\
\hline & \multirow[t]{2}{*}{ Model } & \multicolumn{2}{|c|}{$\begin{array}{l}\text { Unstandardized } \\
\text { Coefficients }\end{array}$} & \multirow{2}{*}{$\begin{array}{l}\text { Standardize } \\
\mathrm{d} \\
\text { Coefficients } \\
\text { Beta }\end{array}$} & \multirow[t]{2}{*}{$\mathrm{T}$} & \multirow[t]{2}{*}{ Sig. } \\
\hline & & $\mathrm{B}$ & Std. Error & & & \\
\hline \multirow{3}{*}{1} & (Constant) & $-5,557$ & 1,262 & & $-4,402$ &, 000 \\
\hline & Ln_Penjualan Bersih & 1,068 & ,201 & ,753 & 5,306 & 000 \\
\hline & $\begin{array}{l}\text { Ln_Beban Umum \& } \\
\text { Administrasi }\end{array}$ &, 148 & ,191 &, 110 &, 773 & ,441 \\
\hline
\end{tabular}

a. Dependent Variable: Ln_Laba Tahun Berjalan

Berdasarkan tabel uji regresi di atas, maka dapat diperoleh persamaan regresi sebagai berikut: $\mathrm{Y}=(-5,557)+1,068 \mathrm{X}_{1}+0,148 \mathrm{X}_{2}+\mathrm{e}$

\section{Hasil Uji Koefisien Determinasi (Adjusted R2)} Model Summary ${ }^{b}$

\begin{tabular}{lrrrr}
\hline Model & $\mathrm{R}$ & $\mathrm{R}$ Square & $\begin{array}{c}\text { Adjusted R } \\
\text { Square }\end{array}$ & $\begin{array}{c}\text { Std. Error of the } \\
\text { Estimate }\end{array}$ \\
\hline 1 &, $855^{\mathrm{a}}$ &, 731 &, 724 & 1,05626 \\
\hline
\end{tabular}

a. Predictors: (Constant), Ln_Beban Umum \& Administrasi, Ln_Penjualan Bersih

b. Dependent Variable: Ln_Laba Tahun Berjalan

Koefisien determinasi (adjusted $R$ Square) menunjukkan seberapa besar variabel independen dapat menjelaskan variabel dependen (Ghozali, 2004:84). Hasil output SPSS pada tabel di atas menunjukkan koefisien determinasi (adjusted $R^{2}$ ) sebesar 0,724 atau 72,4\%. Hal ini berarti variasi dari variabel dependen berupa laba tahun berjalan mampu dijelaskan oleh variasi variabel independen berupa penjualan bersih dan beban umum \& administrasi sebesar $72,4 \%$ dan sisanya sebesar $27,6 \%$ dijelaskan oleh faktor lain seperti: kondisi pertumbuhan perekonomian indonesia, perkembangan pembangunan, kondisi kenaikan harga-harga, dan informasi lainnya. 


\begin{tabular}{|c|c|c|c|c|c|c|}
\hline & & $\begin{array}{l}\text { Hasil U } \\
\text { oefficie }\end{array}$ & $\begin{array}{l}\text { i Parsial } \\
\text { ts }^{\mathrm{a}}\end{array}$ & Uji-t) & & \\
\hline & Model & $\begin{array}{r}\text { Unstanc } \\
\text { Coeff }\end{array}$ & $\begin{array}{l}\text { ardized } \\
\text { cients }\end{array}$ & $\begin{array}{l}\text { Standardized } \\
\text { Coefficients }\end{array}$ & $\mathrm{T}$ & Sig. \\
\hline & & B & Std. Error & Beta & & \\
\hline & (Constant) & $-5,557$ & 1,262 & & $-4,402$ & ,000 \\
\hline & Ln_Penjualan Bersih & 1,068 & ,201 & ,753 & 5,306 & ,000 \\
\hline & $\begin{array}{l}\text { Ln_Beban Umum \& } \\
\text { Administrasi }\end{array}$ & ,148 & 191 & , 110 &, 773 & 441 \\
\hline
\end{tabular}

a. Dependent Variable: Ln_Laba Tahun Berjalan

Sumber: output pengolahan data SPSS versi 21 (2016)

Berdasarkan hasil tabel uji t di atas, maka diperoleh hasil sebagai berikut : a). Nilai t hitung untuk variabel Penjualan Bersih sebesar 5,306 dengan nilai signifikan 0,000. Hasil uji tersebut menunjukkan $t$ hitung lebih besar dari $t$ tabel $(5,306>1,998)$. Dilihat signifikansinya, nilai signifikansi Penjualan Bersih adalah sebesar 0,000 lebih kecil dari nilai signifikan sebesar 0,05 . Hasil perhitungan baik melalui t hitung maupun nilai signifikan, menunjukkan bahwa H0 ditolak dan H1 diterima, artinya secara parsial ada pengaruh signifikan penjualan bersih terhadap laba tahun berjalan. Jadi dari kasus ini dapat disimpulkan bahwa secara parsial penjualan bersih berpengaruh signifikan terhadap laba tahu berjalan pada perusahaan sektor industri dasar dan kimia yang terdaftar di Bursa Efek Indonesia. b). Nilai t hitung untuk variabel Beban Umum \& Administrasi sebesar 0,773 dengan nilai signifikan 0,441. Hasil uji tersebut menunjukkan $t$ hitung lebih kecil dari $t$ tabel $(0,773<1,998)$. Dilihat signifikansinya, nilai signifikansi Beban Umum \& Administrasi adalah sebesar 0,441 lebih besar dari nilai signifikan sebesar 0,05 . Hasil perhitungan baik melalui $\mathrm{t}$ hitung maupun nilai signifikan, menunjukkan bahwa $\mathrm{H} 0$ diterima dan $\mathrm{H} 2$ ditolak, artinya secara parsial tidak ada pengaruh signifikan antara beban umum \& administrasi terhadap laba tahun berjalan. Jadi dari kasus ini dapat disimpulkan bahwa secara parsial beban umum \& administrasi tidak berpengaruh signifikan terhadap laba tahun berjalan pada perusahaan sektor industri dasar dan kimia yang terdaftar di Bursa Efek Indonesia. Berdasarkan hasil uji parsial, variabel X1 dalam penelitian ini adalah penjualan bersih berpengaruh signifikan terhadap laba tahun berjalan pada perusahaan industri dasar \& kimia yang terdaftar di Bursa Efek Indonesia periode 2011-2015. Hasil penelitian ini konsisten dengan hasil penelitian Meiza Efilia (2014) yang menyatakan bahwa secara parsial pendapatan berpengaruh signifikan positif terhadap laba. Berdasarkan hasil uji parsial, variabel X2 dalam penelitian ini adalah beban umum \& administrasi tidak berpengaruh signifikan terhadap laba tahun berjalan pada perusahaan industri dasar \& kimia yang terdaftar di Bursa Efek Indonesia periode 2011-2015. Hal ini mungkin disebabkan karena beban umum \& administrasi tidak mendominasi dalam pengurangan terhadap laba. Karena masih ada beberapa beban lainnya yang bersumber dari biaya operasi, penjualan dan pajak yang tidak dikaitkan dalam beban yang penulis teliti. Karena pada dasarnya yang penulis teliti adalah beban yang hanya berhubungan dengan fenomena ekonomi saat ini yaitu berkaitan dengan beban umum \& administrasi. Sehingga naik turunnya beban umum \& administrasi tidak mempengaruhi laba tahun berjalan yang dihasilkan perusahaan. Oleh karena itu, hasil statistik yang menyatakan beban umum \& administrasi tidak memiliki pengaruh signifikan terhadap nilai laba tahun berjalan dapat diterima, dengan asumsi pengurangan beban umum \& administrasi perusahaan tidak diimbangi oleh peningkatan laba tahun berjalan perusahaan, sehingga hal ini otomatis tidak mempengaruhi laba tahun berjalan yang dihasilkan perusahaan. Hasil penelitian ini konsisten dengan hasil penelitian Fadhillah Ramadhani Nasution, Lisa Marlina (2012) yang menyatakan bahwa secara parsial beban umum \& administrasi tidak berpengaruh signifikan terhadap laba. 
Nilai koefisien determinasi sebesar 0,724 , yang berarti $72,4 \%$ laba tahun berjalan dipengaruh oleh penjualan bersih dan beban umum \& administrasi. Dengan demikian penjualan bersih dan beban umum \& administrasi dapat dijadikan sebagai bahan pertimbangan dalam menilai laba tahun berjalan pada perusahaan industri dasar \& kimia yang terdaftar di Bursa Efek Indonesia.

\section{KESIMPULAN DAN SARAN}

Berdasarkan hasil analisis dan pembahasan yang telah diuraikan pada bab-bab sebelumnya dan pengujian yang telah dilakukan maka dapat diambil kesimpulan sebagai berikut:a).Penjualan bersih (X1) berpengaruh signifikan terhadap laba tahun berjalan pada perusahaan sektor industri dasar dan kimia yang terdaftar di Bursa Efek Indonesia pada periode 2011-2015. b). Beban umum \& administrasi (X2) tidak berpengaruh signifikan terhadap laba tahun berjalan pada perusahaan sektor industri dasar dan kimia yang terdaftar di Bursa Efek Indonesia pada periode 2011-2015. c).Variabel penjualan bersih dan beban umum \& administrasi secara simultan berpengaruh signifikan terhadap laba tahun berjalan pada perusahaan sektor industri dasar dan kimia yang terdaftar di Bursa Efek Indonesia pada periode 2011-2015. Berdasarkan penelitian yang telah dilakukan maka dapat dikemukakan saran sebagai berikut: 1), Bagi peneliti selanjutnya, hendaknya memperluas variabel yang akan diteliti, periode dan sampel penelitian yang akan diteliti seperti dalam sektor manufaktur, pertanian, pertambangan, industri dasar dan kimia, aneka industri, industri barang dan konsumsi, dan sektor lainnya, sehingga hasil penelitian akan lebih valid dan representatif, misalnya menambah sub sektor lain yang ada dalam perusahaan manufaktur yang terdaftar di Bursa Efek Indonesia. 2). Penelitian selanjutnya diharapkan dapat menambah faktor-faktor lain yang mempengaruhi variable dependen di luar dari variabel penjualan bersih dan beban umum \& administrasi, seperti beban penjualan, beban promosi, pajak dan lainnya diluar dari variabel dalam penelitian ini. 3). Perusahaan sebaiknya mempertimbangkan untuk menggunakan variabel yang berpengaruh terhadap laba tahun berjalan dalam hal ini penjualan bersih dan beban umum \& administrasi.

\section{DAFTAR PUSTAKA}

Abdellah Hajiheydari, (2011). The Effect of Research and Development Costs on the Profitability of Pharmaceutical Companies

Akuntansi Manajerial. Edisi Kesebelas. Buku Kesatu. (Diterjemahkan oleh: Nuri Hinduan, S.E., Ak.). Jakarta: Salemba Empat

Anwar, Sanusi, (2011), Metodologi Penelitian Bisnis, Cetakan Kelima, Salemba Empat.

Arief Darmawan \& Rifqi Alifka, (2012). Analisis Pengaruh Harga Pokok Penjualan terhadap Laba Kotor PT

Fadhillah Ramadhani Nasution \& Lisa Marlina, (2011) Pengaruh Biaya Operasional Terhadap Laba Bersih Bank Swasta.

Garrison, Ray H., Eric W. Noreen, dan Peter C. Brewer (2006).

Gujarati, Damodar N.,(2003). Basic Econometrics (4th Edition), New York: McGraw-Hill 
Hansen, Don R. dan Maryane M. Mowen (2007). Akuntansi Manajemen Edisi Ketujuh. Diterjemahkan oleh: Dewi Fitriasari, M.Si dan Deny Amos Kwary, M. Hum. Penerbit Salemba Empat, Jakarta

I Made Wirartha. 2006. Metodologi Penetilian Sosial Ekonomi. Yogyakarta: C.V Andi Offset. Meiza Efilia, (2014 ). Pengaruh Pendapatan Usaha dan Beban Operasional terhadap Laba Bersih pada Perusahaan Kimia dan Keramik, Porselin \& Kaca yang terdaftar di Bursa Efek Indonesia periode 2008-2012

Mufida Warni \& Chumairoh, (2012). Analisis Pengaruh Penjualan Bersih terhadap Laba Kotor PT Nippon Indosari Corpind

Mulyadi, (2009), Akuntansi Biaya. Edisi 5, Cetakan ke 9, penerbit STIM YKPN.

Nazir (2009). Metodologi Penelitian. Indonesia: Ghalia

Ni Komang Tri Utari Dewi, (2014). Pengaruh Pendapatan dan Biaya terhadap Net Income pada Lembaga Perkreditan Desa (LPD) Desa Pakraman Batumulapan Di Kecamatan Nusa Penida

Nikodem Szumilo and Franz Fuerst, (2013). The Operating Expense Puzzle of U.S. Green Office Buildings

Soemarso.(1999). Akuntansi Suatu Pengantar. [Online] Tersedia: http://srinurjanahapriani.blogspot.co.id/2013/11/ [17 Maret 2016]

Supriyono, R. 2011. Akuntansi Biaya, Perencanaan dan pengndalian biaya, serta pengambilan keputusan. Yogyakarta :BPFE

Surya, Raja Adri Satriawan. (2012). Akuntansi Keuangan Versi IFRS. Yogyakarta: Graha Ilmu Yogyakarta

Winardi, 1999, Pengantar Manajemen Penjualan, Bandung: PT. Citra Aditya Bakti

Zain, Mohammad. (2017). Manajemen Perpajakan. Jakarta: Salemba Empat

Zaki Baridwan. (2000;31). Intertmediate Accounting [Online]. (2005). Edisi Ketujuh. Jakarta: Salemba empa

Rahardjo, Budi (2007). Keuangan dan Akuntansi untuk Manajer Non Keuangan Yogyakarta: Graha Ilmu. 